\title{
Original article: \\ The Effect of Combination of Quercetin And Glibenclamide on Myocardial Nuclear Factor Erythroid 2-Related Factor 2 (Nrf2) Expression In Type 2 Diabetic Rat
}

\begin{abstract}
Background. Diabetes mellitus (DM) is a metabolic disorder syndrome that marked by hyperglycemia. The main macrovascular complication is heart failure due to diabetic cardiomyopathy. Hyperglycemia can increase reactive oxygen species (ROS) and lipid peroxidation that induce cellular damage. Quercetin is an antioxidant that reduce hyperglycemia and ROS by modify the expression of nuclear factor erythroid 2-related factor 2 ( Nrf 2). Objective. The aim of this research was to investigate the effect of combination of quercetin and glibenclamide on myocardial nuclear factor erythroid 2-related factor 2 (nrf 2) expression in type 2 diabetic rat compared with no combination. Methods. The rats were divided randomly into nine groups (each group consisted of four rats). The control group consist of a normal group that received placebo, DM control groups that received placebo and glibenclamide and intervention groups received quercetin 5,20 and $80 \mathrm{mg} / \mathrm{kgbw} /$ day and combination of quercetin with $5 \mathrm{mg} / \mathrm{kgbw} /$ day of glibenclamide orally for a period of four weeks. The expression of myocardial Nrf 2 was measured by immunohistochemistry. Data was analyzed by ANOVA and $\mathrm{p}<0.05$ was considered as significant. Results. Twenty and $80 \mathrm{mg} / \mathrm{kgbw} /$ day of quercetin with or without combination with glibenclamide orally for a period of four weeks increase myocardial Nrf2 expression higher than placebo $(\mathrm{p}<0.05)$. Eighty $\mathrm{mg} / \mathrm{kgbw} /$ day of quercetin increase myocardial Nrf2 expression higher than 5 and $20 \mathrm{mg} / \mathrm{kgbw} / \mathrm{day}(\mathrm{p}<0.05)$. Conclusion. From this study it can be suggested that there are significant different in expression level of myocardial Nrf2 of type $2 \mathrm{DM}$ after a combination of quercetin and glibenclamide, quercetin alone, glibenclamide alone and placebo.
\end{abstract}

Hendrawati, $A^{1}$, Akhmad, S.A2, Sadewa, A.H $H^{3}$, Tasmini ${ }^{4}$

Kevwords: Quercetin; glibenclamide; Nuclear factor erythroid 2-related factor 2 (Nrf 2); immuno histochemistry; type 2 diabetes mellitus.

Bangladesh Journal of Medical Science Vol. 16 No. 02 April'17. Page : 302-306

\section{Background}

Diabetes mellitus (DM) is a metabolic disorders syndrome that marked by chronic hyperglycemia, caused by defect in insulin secretion, insulin work or both that cause carbohydrate, protein and lipid metabolic disorders ${ }^{1}$. Diabetes mellitus is an uncurable disease. In 2005, about 135 million peoples in the world (about 3\%) suffered from DM ${ }^{2}$. Its prevalence in the world can raise to 522 million peoples in $2030^{3}$. Data from National Institutes of Health (NIH), about $90-95 \% \mathrm{DM}$ is type $2 \mathrm{DM}^{4}$. In Indonesia, there was about 8.4 million peoples suffered from DM and the number will raises to 21.3 million people in $2030^{5}$.

Diabetes mellitus complication is the main cause of its mortality. Chronic hyperglycemia is the main cause of microvascular complication like retinopathy, neuropathy, nefropathy and macrovascular complication especially cardiomyopathy. Hyperglycemia causes pathologic oxidant, raising lipid peroxidation and reactive oxygen species (ROS) which increase oxidative stress ${ }^{6}$.

Reducing the amount of reactive oxygen species is the main strategy to prevent the DM complications.

1. Asri Hendrawati, Department of Biochemistry Faculty of Medicine Islamic University of Indonesia, Asri Hendrawati, Email: asri_xabi@yahoo.com

2. Syaefudin Ali Akhmad, Department of Biochemistry Faculty of Medicine Islamic University of Indonesia

3. A.H Sadewa, Department of Biochemistry Faculty of Medicine Gadjah Mada University

4. Tasmini, Department of Biochemistry Faculty of Medicine Gadjah Mada University

Correspondence to: Asri Hendrawati, Department of Biochemistry Faculty of Medicine Islamic University of Indonesia, Asri Hendrawati, Email: asri_xabi@yahoo.com 
Antioxidant, for example superoxide dismutase (SOD), can reduces reactive oxygen species by pathologic oxidant scavenging. Antioxidant production mainly induced by nuclear factor erythroid 2-related factor 2 (Nrf2) system which activated by oxidative stress. The active Nrf2 can induce antioxidant response element (ARE) which stimulate transcription of genes that encodes antioxidant enzyme production like SOD, heme oxygenase (HO-1), catalase, glutathione S-transferase (GST) and NAD(P)H:quinone oxidoreductase-1 (NQO1) ${ }^{7}$. In recent years, various type of antioxidant including flavonoid were used for the management of DM. Quercetin is one of flavonoid antioxidant which raise Nrf2 expression and also can reduces lipid peroxidation ${ }^{8}$.

\section{Methods}

This research is an experimental research. This research have approved by Medical and Health Research Ethics Committee (MHREC) Faculty of Medicine Gadjah Mada University, Indonesia with ethical approval no. KE/FK/84/EC. Independent variable were quercetin and glibenclamide dose, dependent variable were myocardial Nrf2 expression whereas restrained variable are food, sex, age and weight. The subject is 36 male Wistar rats age of 3 months and weight of 150-250 grams. Rats were divided into 9 groups, 4 rats each of group. The groups seen in Table 1 .

Table 1. Distribution of treatment groups

\begin{tabular}{|c|l|}
\hline Group & \multicolumn{1}{|c|}{ Intervention } \\
\hline $\mathrm{K} 1$ & 1. normal rat group, received placebo/day \\
\hline $\mathrm{K} 2$ & 2. DM rat group, received plasebo/day \\
\hline $\mathrm{K} 3$ & DM rat group, received glibenclamide $5 \mathrm{mg} / \mathrm{kgbw} /$ day \\
\hline $\mathrm{K} 4$ & DM rat group, received quercetin $5 \mathrm{mg} / \mathrm{kgbw} /$ day \\
\hline $\mathrm{K} 5$ & DM rat group, received quercetin $20 \mathrm{mg} / \mathrm{kgbw} /$ day \\
\hline $\mathrm{K} 6$ & DM rat group, received quercetin $80 \mathrm{mg} / \mathrm{kgbw} /$ day \\
\hline $\mathrm{K} 7$ & $\begin{array}{l}\text { DM rat group, received quercetin } 5 \mathrm{mg} / \mathrm{kgbw} / \text { day and } \\
\text { glibenclamide } 5 \mathrm{mg} / \mathrm{kgbw} / \text { day }\end{array}$ \\
\hline $\mathrm{K} 8$ & $\begin{array}{l}\text { DM rat group, received quercetin } 20 \mathrm{mg} / \mathrm{kgbw} / \text { day } \\
\text { and glibenclamide } 5 \mathrm{mg} / \mathrm{kgbw} / \text { day }\end{array}$ \\
\hline $\mathrm{K} 9$ & $\begin{array}{l}\text { DM rat group, received quercetin } 80 \mathrm{mg} / \mathrm{kgbw} / \text { day } \\
\text { and glibenclamide } 5 \mathrm{mg} / \mathrm{kgbw} / \text { day }\end{array}$ \\
\hline
\end{tabular}

The groups consist of a normal group and 8 DM groups. Rats in a DM group were induced with streptozotocin (STZ) of $60 \mathrm{mg} / \mathrm{kgbw}$ intraperitoneally. After 15 minutes, rats were injected with nicotinamide of $120 \mathrm{mg} / \mathrm{kgbw}$ intraperitoneally. A week later, fasting blood glucose was measured .
Rats with fasting blood glucose level more than 126 $\mathrm{mg} / \mathrm{dL}$ were included as type 2 diabetic $^{9}$.

Quercetin and glibenclamide were administered orally for a period of 4 weeks. After 4 weeks, all rats were decapitated. Fasting blood glucose level was measured with GOD-PAP method before administration of quercetin, glibenclamide or the both combination (pretest) and before decapitation (posttest). The expression of $\mathrm{Nrf2}$ was examined with immunohistochemistry (IHC).

Measuring fasting blood glucose level with GODPAP method

Blood withdrawn from sinus orbitalis. Rats fasting for a period of 12 hours before examination. As many as $10 \mu \mathrm{L}$ blank (aquabidest), sample and standart was put into tubes then added with $1000 \mu \mathrm{L}$ of glucose kit solution. Then the solution was incubated for a period of 10 minutes at $37^{\circ} \mathrm{C}$. The absorbance was determined at $500 \mathrm{~nm}$ wave length.

Measuring myocardial Nrf2 expression with immunohistochemistry (IHC)

The heart tissue was fixed with formaline buffer. Then paraffin block was made on vertical slice. Myocardial Nrf2 expression was measured with immunohistochemistry. Positive Nrf2 expression was shown with brown colour in the nucleus and negative Nrf2 expression was shown with blue colour in the nucleus. Percentage of Nrf2 expression was calculated by the ratio of positive cells that expressed Nrf2 in the nucleus and total of cells. $\underline{\text { Result analysis }}$

Myocardial Nrf2 expression was analysed with One Way ANOVA if it was normally distributed or with Kruskal-Wallis ANOVA if it was not normally distributed.

\section{Result and discussion}

Characteristic of the research subject Rats Weight

Weight data between groups at pretest and posttest measurements were analyzed by One Way ANOVA test. The weight was not significantly different between groups $(p>0.05)$ on the pretest and posttest measurements. Then, the difference between pretest to posttest was analyzed using a paired $t$ test for each group. The mean of body weight of rats decreased significantly at posttest measurements in groups of $\mathrm{K} 5$ and $\mathrm{K} 9$, but not significantly in the group $\mathrm{K} 2, \mathrm{~K} 3, \mathrm{~K} 6, \mathrm{~K} 7$ and $\mathrm{K} 8$. The mean body weight was not significantly increase in the group $\mathrm{K} 1$ and K4. Table 2 shows the mean body weight of rats at pretest and posttest measurements. 
Table 2. Mean of rat body weight at pretest and posttest measurements (grams)

\begin{tabular}{cccc}
\hline Group & $\begin{array}{c}\text { Pretest mean body } \\
\text { weight }\end{array}$ & $\begin{array}{c}\text { Posttest mean } \\
\text { body weight }\end{array}$ & $\mathrm{P} * *$ \\
\hline K1 & $224.25 \pm 3.30$ & $227.75 \pm 29.71$ & \\
K2 & $204.75 \pm 11.18$ & $204.25 \pm 38.68$ & \\
K3 & $200.50 \pm 15.76$ & $174.50 \pm 36.63$ & 0.832 \\
K4 & $201.00 \pm 23.90$ & $214.50 \pm 31.72$ & 0.977 \\
K5 & $226.00 \pm 24.81$ & $179.75 \pm 47.81$ & 0.169 \\
K6 & $200.75 \pm 27.41$ & $185.00 \pm 37.94$ & 0.030 \\
K7 & $211.75 \pm 20.09$ & $207.75 \pm 54.66$ & 0.469 \\
K8 & $191.50 \pm 18.43$ & $185.00 \pm 37.94$ & 0.834 \\
K9 & $192.50 \pm 13.43$ & $167.50 \pm 8.81$ & 0.012 \\
P* & 0.138 & 0.373 & \\
\hline
\end{tabular}

The mean body weight in diabetic rats group at posttest measurements tended to decline when compared with that of pretest measurements except in the group of diabetic rats fed with quercetin dose of $5 \mathrm{mg} / \mathrm{kgbw} /$ day. Mean body weight of normal group increased but not significantly different.

Insulin resistance occurs in type 2 DM. Cells can not use glucose because of reduces glucose uptake by particular cell. These cells cannot utilize glucose as an energy source and lead to the use of fat and protein reserves. There will be an increase in lipolysis and decreased lipogenesis as compensation, which cause weight loss ${ }^{10}$.

Weight loss in rats fed with quercetin may be caused by the effects of quercetin itself. Based on previous studies 20 to $625 \mathrm{mg} / \mathrm{kgbw} /$ day orally of quercetin given for 8 weeks resulted in significant weight loss due

Table 3. Mean of FBG level at pretest and posttest measurements $(\mathrm{mg} / \mathrm{dL})$

\begin{tabular}{cccc}
\hline Group & Pretest FBG & Posttest FBG & $\mathrm{P}^{* *}$ \\
\hline K1 & $103.01 \pm 14.52$ & $72.81 \pm 15.17$ & 0.025 \\
K2 & $143.33 \pm 15.81$ & $166.21 \pm 35.90$ & 0.391 \\
K3 & $206.35 \pm 60.99$ & $291.55 \pm 258.29$ & 0.553 \\
K4 & $202.30 \pm 81.31$ & $171.56 \pm 38.87$ & 0.581 \\
K5 & $224.57 \pm 110.87$ & $366.33 \pm 72.34$ & 0.841 \\
K6 & $296.12 \pm 126.29$ & $284.53 \pm 193.52$ & 0.782 \\
K7 & $162.67 \pm 22.69$ & $156.98 \pm 42.91$ & 0.638 \\
K8 & $257.38 \pm 90.43$ & $319.07 \pm 148.14$ & \\
K9 & $291.17 \pm 151.03$ & $393.69 \pm 153.26$ & \\
P $*$ & 0.014 & 0.012 & \\
\hline
\end{tabular}
to the ability of quercetin in increasing lipolysis, increasing fatty acid oxidation and decrease adipogenesis ${ }^{11}$.

\section{Fasting blood glucose level}

Differences in fasting blood glucose (FBG) level between the groups were analyzed using nonparametric test of Kruskal-Wallis. There were at least two groups that have significant different of FBG level $(\mathrm{p}<0.05)$ at pretest and posttest measurements. Then post hoc analyzes was performed using the Mann-Whitney test. There was a significant different of FBG level between $\mathrm{K} 1$ and $\mathrm{K} 2$ to $\mathrm{K} 9$ groups at pretest and posttest measurements.

Differences in FBG level between rats in each group at pretest and posttest measurements were tested using the decrease of FBG level in K1 group. There was no significant decrease in mean FBG level of $\mathrm{K} 4$ and $\mathrm{K} 7$ groups. There was no significant increase of mean FBG level in the K2, K3, K5, K6, $\mathrm{K} 8$ and $\mathrm{K} 9$ groups.

Large variations in FBG level between groups was likely due to the differences in induction period. This causes unequal distribution of rats between group. In addition, there is a difference period of time to become diabetic rats. There were rats that meet the criteria of DM (FBG $>126 \mathrm{mg}$ / dL) at 1 week, others meet the criteria of DM after 3 weeks post-induction. Table 3 shows the mean of FBG level at pretest and posttest measurements. paired $t$ test. There was a significant 
liver, increase the number of pancreatic beta cells and reduce glucose absorption in the small intestine ${ }^{12}$.

Myocardial nuclear factor erythroid 2-related factor 2 (Nrf2) expression

Positive expression of nuclear factor erythroid 2-related factor 2 (Nrf2) in rat myocardial is shown as brown color, whereas negative expression is shown as blue color in the cell nucleus. Immunohistochemistry image of the myocardial which expressed Nrf2 on cell nucleus and which are not is shown in Figure 1.

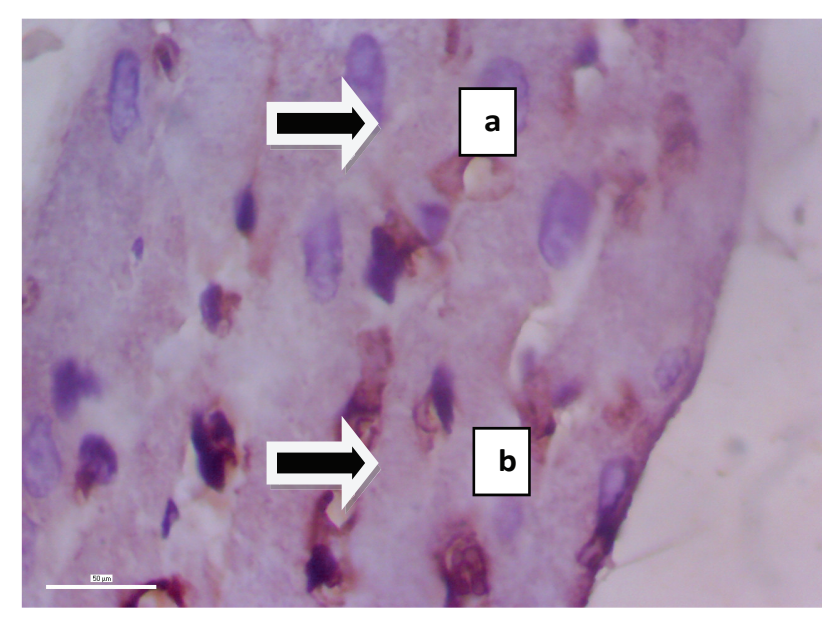

$a=$ the myocardial which not expressed $\mathrm{Nrf} 2$ in cell nucleus, $b=$ the myocardial which expressed Nrf2 in cell nucleus

Figure 1. Immunohistochemistry image of the myocardial which expressed Nrf2 in cell nucleus and which are not

In the calculation of percentage of myocardial Nrf2, expression K1 group was the lowest whereas K9 group was the highest percentage. There was significant different of myocardial Nrf2 expression between groups $(p<0.05)$. Post-hoc test showed the significant different between $\mathrm{K} 1$ and $\mathrm{K} 2$ to K9 groups. Table 4 shows the mean percentage of myocardial Nrf2 expression.
Table 4. Mean percentage of myocardial Nrf2 expression (\%)

\begin{tabular}{ccc}
\hline Group & $\begin{array}{c}\text { Myocardial Nrf2 } \\
\text { expression (\%) }\end{array}$ & $\mathrm{P}^{*}$ \\
\hline K1 & $2.95 \pm 0.56$ & 0.000 \\
K2 & $6.71 \pm 0.56$ & \\
K3 & $11.34 \pm 0.69$ & \\
K4 & $6.77 \pm 1.99$ & \\
K5 & $13.07 \pm 1.19$ & \\
K6 & $15.14 \pm 1.44$ & \\
K7 & $11.51 \pm 1.94$ & \\
K8 & $9.91 \pm 1.17$ & \\
K9 & $17.76 \pm 3.69$ & \\
\hline
\end{tabular}

There was an increase in expression of myocardial Nrf2 significantly in the rat groups were induced into DM when compared with the normal group. Type 2 DM is characterized by chronic hyperglycemia, lead to an increase in free radicals and oxidative stress more than normal conditions that induced an increase in the release of Nrf2 from Keap1 protein in the cytoplasm. The Nrf2 will translocate to the nucleus so that Nrf2 expression increased in cell nucleus ${ }^{13}$. In this study, rats that received $80 \mathrm{mg} / \mathrm{kgbw} /$ day of quercetin have the highest increases in cardiac muscle Nrf2 expression when compared with that of the groups received placebo, glibenclamide, 5 and 20 $\mathrm{mg} / \mathrm{kgbw} /$ day of quercetin. Giving glibenclamide in combination with quercetin had no effect in increasing myocardial Nrf2 expression compared with that of quercetin alone. Previous studies showed that the dose of quercetin affect its ability to reduce oxidative stress in DM rat ${ }^{14}$.

\section{Conclusion}

From this study it can be suggested that there are significant different in expression level of myocardial Nrf2 of type 2 DM after received a combination of quercetin and glibenclamide, quercetin alone, glibenclamide alone and placebo. 


\section{References:}

1. American Diabetes Association. Diagnosis and classification of diabetes mellitus. Diabetes Care 2012; 35:64-71.

2. Murugesh KV, Yeligar DK, Dash P, Sengupta $\mathrm{BC}$, and Maity TK. Antidiabetic, antioxidant and antihyperlipidemic status of Heliotropium zeylanicum extract on streptozotocin- induced diabetic rats. Biol. Pharm. Bull, 2006; 29: 22025 .

3. Whiting DR, Guariguata L, Weil C, Shaw J. IDF Diabetes Atlas: Global estimates of the prevalence of diabetes for 2011 and 2030. Diabetes Res. Clin. Pract 2011; 94: 311-21.

4. Riaz S. Diabetes mellitus. Sci Res Essays 2009; 4 (5): 367-373.

5. Perkumpulan Endokrinologi Indonesia (PERKENI). Konsensus Pengelolaan dan Pencegahan Diabetes Melitus Tipe 2 di Indonesia 2006. PB. PERKENI:Jakarta.

6. Goh SY and Cooper ME. The role of advanced glycation end products in progression and complications of diabetes. J Clin Endocrinol Metab. 2008; 93:1143-52.

7. Pi J, Zhang Q, Fu J, Woods CG, Hou Y, Corkey BE. ROS signaling, oxidative stres and Nrf2 in pancreatic beta-cell function. Toxicol Appl Pharmacol 2010; 244:77-83.

8. Aguirre L, Arias N, Maraculla MT, Gracia A, Portillo MP. Beneficial effects of quercetin on obesity and diabetes. Open Nutraceuticals J
2011; 4:189-198.

9. Barik R, Jain S, Qwatra D, Joshi A, Tripathi GS and Goyal R. Antidiabetic activity of aqueous root extract of Ichnocarpus frutescens in streptozotocin-nicotinamide induced typeII diabetes in rats. Indian J Pharmacol 2008; 40(1):19-22.

10. Murray RK, Granner DK, Mayes PA and Rodwell VW. Biokimia Harper. Edisi 24. 1999. Penerjemah: Hartono, A. Jakarta: EGC.

11. Lai CY, Yang JY, Rayalam S. Preventing Bone Loss and Weight Gain with Combinations of Vitamin D and Phytochemicals. J Med Food. 2011;14(11):1352-62.

12. Vessal M, Hemmati M, Vasei M. Antidiabetic effects of quercetin in streptozocin-induced diabetic rats. Comp Biochem Physiol C: Comp Pharmacol Toxicol, 2003; 135: 357-64.

13. Yu ZW, Li D, Ling WH, Jin TR. Role of nuclear factor (erythroid-derived 2)-like 2 in metabolic homeostasis and insulin action: A novel opportunity for diabetes treatment? World J Diabetes 2012; 3(1): 19-28.

14. Mahesh T and Menon VP. Quercetin allievates oxidative stress in streptozotocin-induced diabetic rats. Phytother Re. 2004; 18( 2):123127.

15. Hendrawati A, Sadewa AH, Tasmini. Efek pemberian kuersetin terhadap Nuclear Factor Erythroid 2-Related Factor 2 (Nrf2) pada otot jantung tikus DM tipe 2. 2013. Thesis in Gadjah Mada University, Indonesia: unpublished. 